\title{
Corrigendum: Thymic Epithelial Cells Contribute to Thymopoiesis and T Cell Development
}

\section{OPEN ACCESS}

Approved by:

Frontiers Editorial Office,

Frontiers Media SA, Switzerland

${ }^{*}$ Correspondence:

Yong Zhao

zhaoy@ioz.ac.cn

Yu-Rong Qiu

qyr@smu.edu.cn

tThese authors have contributed equally to this work

Specialty section:

This article was submitted to

T Cell Biology,

a section of the journal

Frontiers in Immunology

Received: 12 November 2020 Accepted: 16 November 2020

Published: 30 November 2020

Citation:

Wang $H-X$, Pan W, Zheng $L$, Zhong $X-P$, Tan L, Liang Z, He J, Feng P, Zhao Y and Qiu Y-R (2020)

Corrigendum: Thymic Epithelial Cells Contribute to Thymopoiesis and T Cell Development.

Front. Immunol. 11:628464. doi: 10.3389/fimmu.2020.628464

\begin{abstract}
Hong-Xia Wang ${ }^{1,2 t}$, Wenrong Pan ${ }^{3 \dagger}$, Lei Zheng ${ }^{1+}$, Xiao-Ping Zhong ${ }^{4}$, Liang Tan $^{5}$, Zhanfeng Liang ${ }^{2}$, Jing He ${ }^{1}$, Pingfeng Feng ${ }^{1}$, Yong Zhao ${ }^{2 *}$ and Yu-Rong Qiu ${ }^{1 *}$

${ }^{1}$ Laboratory Medicine Center, Nanfang Hospital, Southern Medical University, Guangzhou, China, ${ }^{2}$ State Key Laboratory of Membrane Biology, Institute of Zoology, Chinese Academy of Sciences, Beijing, China, ${ }^{3}$ Department of General Surgery, Taihe Branch of Nanfang Hospital, Southern Medical University, Guangzhou, China, ${ }^{4}$ Division of Allergy and Immunology, Department of Pediatrics, Duke University Medical Center, Durham, NC, United States, ${ }^{5}$ Department of Urological Organ Transplantation, Center of Organ Transplantation, The Second Xiangya Hospital of Central South University, Changsha, China
\end{abstract}

Keywords: thymic epithelial cells (TECs), medullary thymic epithelial cells (mTECs), thymopoiesis, tissue-restricted antigens (TRAs), tolerance

\section{A Corrigendum on}

Thymic Epithelial Cells Contribute to Thymopoiesis and T Cell Development By Wang H-X, Pan W, Zheng L, Zhong X-P, Tan L, Liang Z, He J, Feng P, Zhao Y and Qiu Y-R (2020). Front. Immunol. 10:3099. doi: 10.3389/fimmu.2019.03099

In the original article, there was an error in the Funding statement. The correct numbers for National Nature Science Foundation of China are 81801390 to H-XW and 31800754 to ZL.

The authors apologize for this error and state that this does not change the scientific conclusions of the article in any way. The original article has been updated.

Copyright () 2020 Wang, Pan, Zheng, Zhong, Tan, Liang, He, Feng, Zhao and Qiu. This is an open-access article distributed under the terms of the Creative Commons Attribution License (CC BY). The use, distribution or reproduction in other forums is permitted, provided the original author(s) and the copyright owner(s) are credited and that the original publication in this journal is cited, in accordance with accepted academic practice. No use, distribution or reproduction is permitted which does not comply with these terms. 